\title{
The impact of naturally-occurring, trans-placental bluetongue virus serotype- 8 infection on reproductive performance in sheep
}

\author{
Claude Saegerman ${ }^{\mathrm{a}}$, Benoît Bolkaerts ${ }^{\mathrm{b}}$, Christine Baricalla ${ }^{\mathrm{b}}$, Marianne Raes ${ }^{\mathrm{b}}$, Laetitia Wiggers ${ }^{\mathrm{b}}$, \\ Ilse de Leeuw ${ }^{c}$, Frank Vandenbussche ${ }^{c}$, Jean-Yves Zimmer ${ }^{d}$, Eric Haubruge ${ }^{d}$, Dominique Cassart ${ }^{e}$, \\ Kris De Clercq ${ }^{\mathrm{c}}$, Nathalie Kirschvink ${ }^{\mathrm{b}, *}$
}

a Epidemiology and Risk Analysis Applied to Veterinary Sciences, Department of Infectious and Parasitic Diseases, Faculty of Veterinary Medicine,
University of Liège, 4000 Liège, Belgium
${ }^{\mathrm{b}}$ Animal Physiology, Department of Veterinary Medicine, Faculty of Sciences, University of Namur, 5000 Namur, Belgium
${ }^{\mathrm{c}}$ Veterinary and Agrochemical Research Centre, Department of Virology, 1180 Brussels, Belgium
${ }^{\mathrm{d}}$ Department of Functional and Evolutionary Entomology, Gembloux Agricultural University, 5030 Gembloux, Belgium
${ }^{\mathrm{e}}$ Department of Pathology, Faculty of Veterinary Medicine, University of Liège, 4000 Liège, Belgium

\section{A R T I C L E I N F O}

Article history:

Accepted 17 November 2009

Available online $\mathrm{xxxx}$

\section{Keywords:}

Emerging infectious disease

Bluetongue serotype- 8

Sheep

Trans-placental infection

Abortion

Over-wintering

\begin{abstract}
A B S T R A C T
Infection with bluetongue virus serotype (BTV)-8 occurred in ruminants in 2006 in Central-Western Europe. The trans-placental passage of this virus has been demonstrated in naturally- and experimentally-infected cattle and in experimentally-infected sheep. Trans-placental transmission is potentially important in the 'over-wintering' of this virus and its subsequent impact on reproductive performance. This epidemiological study was carried out on a sheep flock in Belgium that had experienced a severe outbreak of BTV-8 infection, and where the seroprevalence had increased from $1.3 \%$ to $88 \%$ between January and November 2007. In total, 476 lambs and 26 aborted fetuses from 300 ewes, lambing at four distinct time periods, were investigated between November 2007 and May 2008.

The following evidence suggested that BTV-8 infection occurred in utero: (1) positive PCR results from splenic tissue from aborted fetuses $(n=4)$; (2) fetal malformations suggestive of BTV infection $(n=10)$; (3) positive PCR results from red blood cells in-lambs $(n=7)$, and (4) the presence of antibody at birth in viable lambs prior to the intake of colostrum $(n=9)$. The evidence provided by this investigation strongly suggests that trans-placental BTV-8 infection occurs in naturally-infected sheep and the impact of infection on the reproductive performance of such a naïve flock was considerable, with up to $25 \%$ of ewes aborting and with flock fertility reduced by $50 \%$. The contribution of in utero-infected lambs to the over-wintering of BTV appears limited.
\end{abstract}

(c) 2009 Elsevier Ltd. All rights reserved.

\section{Introduction}

Bluetongue (BT) is an infectious, non-contagious disease of ruminants caused by an arthropod-borne virus of the family Reoviridae, genus Orbivirus. The BT virus (BTV) includes 24 serotypes which are transmitted by haematophagus insects of the family Ceratopogonidae, genus Culicoides (Mellor and Wittmann, 2002). In cattle, goats and most wild ruminants, BT is mostly sub-clinical, but infection in sheep causes severe clinical signs such as nasal discharge, salivation, subcutaneous oedema (particularly of the head), ulceration of the oral mucosa, and occasionally cyanosis of the tongue (MacLachlan, 1994; Saegerman et al., 2007; Lefèvre et al., 2008).

Until recently, the distribution of BTV serotypes $1,2,4,9,15$ and 16 was restricted to the Mediterranean basin, the Balkans and Cen-

\footnotetext{
* Corresponding author. Tel.: +32 817243 79; fax: +32 81724376

E-mail address: Nathalie.Kirschvink@fundp.ac.be (N. Kirschvink).
}

tral Europe, and between 1998 and 2006, outbreaks of BT, involving different serotypes occurred in Southern and Central Europe (Mellor and Wittmann, 2002; Saegerman et al., 2008a). In the summer of 2006, infection with BTV serotype-8 (BTV-8) occurred in numerous ruminants over a wide area of Central-Western Europe including The Netherlands, Belgium, Germany, and to a lesser extent, Luxemburg and Northern France (Saegerman et al., 2008a). The mean morbidity and mortality rates observed in sheep at the beginning of this epizootic were $20 \%$ and $5 \%$, respectively (Elbers et al., 2007). In 2007, the morbidity and mortality rates increased in sheep older than 1 year to $49.4 \%$ and $9.2 \%$, respectively (Saegerman et al., 2008b). More than 20,000 sheep died of BT in Belgium in 2007 , which represents approximately $5-10 \%$ of the country's sheep population (FASFC, 2007).

Among the economic losses resulting from BTV infection are abortion and those due to congenital deformities such as hydranencephaly and cerebellar aplasia in calves and lambs (Oberst, 1993). The trans-placental passage of infection to ruminant fetuses 
has, until recently, only been associated with the use of BTV modified live vaccines (MacLachlan et al., 2000). BTV serotypes -10, -11 , -13 and -17 are able to cross the placenta and cause fetal infection (MacLachlan et al., 1985, 2000). Trans-placental infection with BTV-8 has occurred in cattle infected since 2006 in Central-Western Europe, resulting in hydranencephaly and abortion (Vercauteren et al., 2008; Wouda et al., 2008). Surviving, viraemic, 'dummy' calves have also been reported (Vercauteren et al., 2008). Of 102 pre-colostral serum samples from calves born from naturally-infected dams, 38 tested positive using a BTV group-specific ELISA (Desmecht et al., 2008). As epitheliochorial placentation in ruminants does not allow the transfer of immunoglobulins (Campbell et al., 1977), the presence of BTV antibodies in the serum of neonatal ruminants, born during periods of insect vector inactivity, strongly suggests in utero infection by BTV. Furthermore, BTV has been isolated from the blood of two neonatal calves prior to ingesting colostrum and BTV-RNA was detected in 11\% of calves with clinical signs suspicious of BT, born during the vector-free period (De Clercq et al., 2008).

As in utero infection by BTV leads to viraemic animals, this process could contribute to the 'over-wintering' of the virus (Wilson and Mellor, 2008). An investigation into the rate of such trans-placental infection in naturally-infected sheep and cattle is thus vital. Although experimental trans-placental infection by BTV-8 in sheep has been described (Worwa et al., 2009), to the authors' knowledge, there are no published data relating to the situation in naturally-infected animals. The aims of the present study were to investigate the possibility of the trans-placental passage of BTV-8 in naturally-infected sheep, to quantify the viral transmission rate in a naïve flock by taking into account vector activity, and to determine whether BTV-8 over-winters in lambs following trans-placental infection.

\section{Materials and methods}

\section{Animal selection}

The sheep flock under investigation was held at the University of Namur, Belgium and consisted of 355 ewes. Of these, 29.3\% were of the Ile de France breed, $27 \%$ were French Texels, 9\% were Dutch Texels, $26.5 \%$ were Texel-Ile de France crossbreeds and $8.2 \%$ were Laitier Belge crossbreeds. The animals were studied between July 2007 and June 2008 and were pastured until approximately day 125 of gestation when they were housed prior to lambing. Both ewes and lambs were housed after lambing. The 23 rams under study were of the French or Dutch Texel, Ile de France or Laitier Belge breeds. The study was approved by the Ethical Committee for Animal Welfare of the University of Namur (Study 06/075).

\section{Clinical history of BTV-8 infection in flock}

Three clinical cases in November 2006 were confirmed by serology and PCR. The BTV seroprevalence in the flock, assessed in January and November 2007 by ELISA (ID-VET), increased from $1.3 \%$ to $88 \%$ between these dates. Approximately $60 \%$ of the ewes had been clinically affected between July and the end of September 2007. Details of each of the 219 clinical cases were recorded including the predominant clinical signs and the duration of treatment (N. Kirschvink et al., unpublished data). Infection was confirmed by the detection of antibody in serum and by PCR detection and virus isolation from red blood cells (Toussaint et al., 2007a; Vandenbussche et al., 2008).

\section{Schedule of breeding and lambing periods}

Four pregnancy (P)-lambing (L) periods were scheduled. In the period P1-L1, 100 ewes were oestrus synchronised in early July 2007 using vaginal progesterone sponges (60 mg medroxyprogesterone acetate, Veramix, Pfizer) and IM injection of $750 \mathrm{IU}$ of pregnant mare serum gonadotrophin (PMSG) (Folligon, Intervet). The ewes underwent exocervical insemination with fresh semen $48-52 \mathrm{~h}$ after vaginal device removal and PMSG injection or were left with a ram to breed naturally. In the P2-L2 period, 114 ewes were left for 17 days with three 'teaser' rams at the end of August 2007 to induce oestrus and were then left for a further 17 days to breed naturally with several rams. For the P3-L3 period, 186 ewes were left with rams for 34 days in October 2007. In the P4-L4 period, following exposure to teaser rams for 17 days, 92 ewes were left with rams for 17 days at the beginning of January 2008.

Rams were equipped with coloured raddles to assess mounting of ewes and pregnancy diagnosis was performed approximately 45 days after the breeding period using ultrasonography. Non-pregnant ewes were re-used for the following period whereas pregnant ewes were pastured separately and housed for lambing around day 125 of pregnancy. Following this schedule, lambing occurred in November 2007 (L1), January 2008 (L2), March 2008 (L3) and May 2008 (L4).

All rams used in natural service or for artificial insemination underwent semen quality assessment (Kirschvink et al., 2009). At the time of breeding they were either free of (period P1) or had completely recovered from (periods P2, P3 and P4) BTV-8 infection. Only rams reaching the semen quality equivalent of that required by the Ovine Insemination and Selection Centre of Namur University (semen motility score $\geqslant 4$, concentration $\geqslant 2.5$ billion spermatozoa $/ \mathrm{mL}, \geqslant 70 \%$ living spermatozoa and $<5 \%$ abnormal spermatozoa) were used (Kirschvink et al., 2009). At lambing, care was taken to insure that each lamb received colostrum from its own ewe and animals were excluded from the study if other colostrum was supplied.

\section{Reproductive performance}

The number of ewes used per breeding period, the number of pregnant ewes after day 45 , the number of lambing ewes, the number of abortions occurring after day 125 of pregnancy and the numbers of live and aborted lambs were carefully recorded for each lambing period. Abortion occurring at pasture between pregnancy diagnosis (day 45) and day 125 was considered 'undetected' because fetuses could not be recovered.

\section{Sample collection during lambing}

Blood was obtained from ewes by jugular puncture from $48 \mathrm{~h}$ before to $48 \mathrm{~h}$ after lambing. Serum aliquots were prepared and kept at $-20^{\circ} \mathrm{C}$ until analysis. Several pieces of placenta were collected $2-4 \mathrm{~h}$ after lambing and were kept at $-20^{\circ} \mathrm{C}$ until analysed. Lambs were blood sampled by jugular puncture immediately after birth and before they ingested colostrum (T0). Serum aliquots were prepared and held at $-20^{\circ} \mathrm{C}$. The lambs were re-sampled $36 \mathrm{~h}$ later when transfer of maternal antibodies had occurred (T36) (N. Kirschvink et al., unpublished data). Twenty randomly selected lambs, in addition to all lambs with positive BTV serology at T0 were blood sampled into EDTA tubes at 14 days (D14). The red blood cells (RBC) were immediately separated and stored at $-80^{\circ} \mathrm{C}$. Where abortions occurred, the ewe was identified and the fetus was subjected to post-mortem examination when tissue autolysis was not too advanced. Wherever possible, the spleen was removed and stored at $-20^{\circ} \mathrm{C}$.

\section{Follow-up sampling of BTV-8 PCR-positive lambs}

Seven clinically normal lambs with positive T0 serology and PCR, born in November 2007, were re-sampled until week 18 . Serum samples were collected bimonthly in order to compare with those from T0 BTV-8-negative lambs that became positive after ingesting colostrum $(n=7)$. Seven lambs born to BTV-8 negative ewes were also included in the follow-up sampling and served as negative controls. All serum samples were stored at $-20^{\circ} \mathrm{C}$.

One 'dummy' lamb with neurological deficits, born in November 2007, had a positive T0 serology but was PCR-negative at D14. This lamb was euthanased at 5 months old, at which time photographs were taken of its cerebrum and samples of cerebrum and spleen were removed and stored at $-80^{\circ} \mathrm{C}$.

\section{Sample analyses}

\section{Serological examination}

A competitive ELISA to detect the VP7 antibody was used (Id-Vet) and results were expressed as a percentage of negativity. All values with a percentage of negativity $<66 \%$ (the cut-off point) were considered positive (Vandenbussche et al., 2008).

\section{RNA detection}

The detection of viral RNA in RBCs, placenta, spleen and brain using a two-step RT-qPCR targeting segment 5 of BTV (RT-qPCR_S5), was performed by the Belgian National Reference Centre for Bluetongue (Veterinary and Agrochemical Research Centre, UCCLE, Belgium). The technique used was as described by Vandenbussche et al. (2008) and the group-specific primers and Taqman probe targeting BTV-segment 5 were as detailed by Toussaint et al. (2007a) but with slight modifications to the extraction method. Briefly, total RNA was purified from $200 \mu \mathrm{L}$ of RBCs by adding $800 \mu \mathrm{L}$ Trizol. After adding $160 \mu \mathrm{L}$ of chloroform and a 15 min centrifugation step at $12,000 \mathrm{~g}$, the aqueous phase was mixed with an equal volume of $100 \%$ ethanol. The extraction was completed using the NucleoSpin RNA Virus Kit (Macherey-Nagel). When a positive result was achieved (cycle threshold [Ct] value $<40$ ), virus isolation was carried out in embryonated chicken eggs (Toussaint et al., 2007b). 
Assessment of Culicoides spp. activity

Culicoides spp. were captured using an ultra-violet 'Onderstepoort Veterinary Institute' (OVI)-type light trap fitted with a $8 \mathrm{~W}$ neon bulb and supplied by a $12 \mathrm{~V}$ battery. This trap was equipped with a multi-blade propeller that dispatched the attracted insects into a soapy water-filled container. An elastic net with a $5 \times 5 \mathrm{~mm}$ mesh was placed between the cover and the central cylinder limiting access to small insects. This mounting was suspended so that the collection bottle was at a height of $1.5 \mathrm{~m}$. Collected samples were placed in $70 \%$ ethanol. The midges were then extracted with the aid of $40 \times$ binocular microscopy. The trapping was performed over a period of $24 \mathrm{~h}$ each week between August 2007 and May 2008. One trap was placed inside the barn where sheep were housed and a second suspended from a tree where the sheep were pastured.

\section{Data analysis}

For each reproductive performance rate (Table 1 ) and percentage positive serology (Table 2 ) the $95 \%$ confidence interval $(\mathrm{CI})$ was determined using a binomial exact distribution. Based on 11 time points (T0 and T36 h and 2, 4, 6, 8, 10, 12, 14, 16 and 18 weeks) and three parameters: (1) lambs born to BTV-8-positive ewes with- out antibodies at T0, (2) lambs born to BTV-8-positive ewes with antibodies at T0, and (3) lambs born to BTV-8-negative ewes without antibodies at T0; with seven lambs/group, a two-factor ANOVA with repeated measures on one factor (antibody to BTV) was used to compare the kinetics of the negativity percentage between groups. The validity conditions (homogeneity of variances and covariance matrix), were previously verified. $P$ values $<0.05$ were considered significant.

\section{Results}

\section{Impact of BTV-8 infection and time of lambing on reproductive performance}

Table 1 details reproductive performance as a function of the four lambing periods and includes detected and undetected abortions as well as the number of live and aborted lambs. The ewe fertility rate (number of pregnant ewes/number of ewes used) as calculated at the time of pregnancy diagnosis, was very low for the January 2008 lambing period, but approached normal values

Table 1

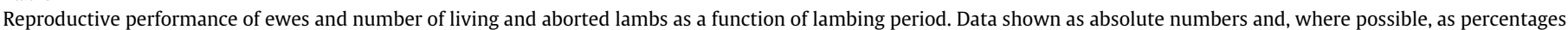
with $95 \%$ confidence intervals.

\begin{tabular}{|c|c|c|c|c|c|c|}
\hline \multirow[t]{2}{*}{ Parameter } & \multirow[t]{2}{*}{ Unit } & \multicolumn{5}{|l|}{ Lambing period } \\
\hline & & November 2007 & January 2008 & March 2008 & May 2008 & Total \\
\hline Number of ewes & Number & 100 & 114 & 186 & 92 & \\
\hline Pregnant ewes * & Number & 70 & 44 & 141 & 54 & 309 \\
\hline Fertility of pregnant ewes & Percentage & 70 & 30.5 & 75.8 & 58.7 & \\
\hline Lambing ewes & Number & 63 & 44 & 139 & 54 & 300 \\
\hline Fertility of lambing ewes & Percentage & 63 & 30.5 & 74.7 & 58.7 & \\
\hline Undetected abortions ${ }^{* *}$ & Number & 7 & 0 & 2 & 0 & 9 \\
\hline Detected abortions ${ }^{* * *}$ & Number & 11 & 0 & 8 & 2 & 21 \\
\hline Live and aborted lambs & Number & 137 & 65 & 224 & 76 & 502 \\
\hline Prolificacy & Number & 2.17 & 1.48 & 1.61 & 1.41 & \\
\hline Live lambs & Number & 121 & 65 & 216 & 74 & 476 \\
\hline Aborted lambs ${ }^{* * *}$ & Number & 16 & 0 & 8 & 2 & 26 \\
\hline Undetected abortions ${ }^{* *}$ & $\begin{array}{l}\text { Percentage } \\
(95 \% \mathrm{CI})\end{array}$ & $\begin{array}{l}10.0 \\
(4.1-19.5)\end{array}$ & $\begin{array}{c}0 \\
(0-6.6)\end{array}$ & $\begin{array}{c}1.4 \\
(0.2-5.0)\end{array}$ & $\begin{array}{l}0 \\
(0-5.4)\end{array}$ & $\begin{array}{c}2.9 \\
(1.3-5.5)\end{array}$ \\
\hline Detected abortions ${ }^{* * *}$ & $\begin{array}{l}\text { Percentage } \\
(95 \% \mathrm{CI})\end{array}$ & $\begin{array}{l}15.7 \\
(8.1-26.4)\end{array}$ & $\begin{array}{c}0 \\
(0-6.6)\end{array}$ & $\begin{array}{l}5.7 \\
(2.5-10.9)\end{array}$ & $\begin{array}{l}3.7 \\
(0.5-12.7)\end{array}$ & $\begin{array}{l}6.8 \\
(4.3-10.2)\end{array}$ \\
\hline Live lambs & $\begin{array}{l}\text { Percentage } \\
(95 \% \mathrm{CI})\end{array}$ & $\begin{array}{l}88.3 \\
(81.7-93.2)\end{array}$ & $\begin{array}{l}100 \\
(95.5-100)\end{array}$ & $\begin{array}{l}96.5 \\
(93.1-98.4)\end{array}$ & $\begin{array}{l}97.4 \\
(90.8-99.7)\end{array}$ & $\begin{array}{c}94.6 \\
(92.3-96.4)\end{array}$ \\
\hline Aborted lambs ${ }^{* * *}$ & $\begin{array}{l}\text { Percentage } \\
(95 \% \mathrm{CI})\end{array}$ & $\begin{array}{l}11.7 \\
(6.8-18.3)\end{array}$ & $\begin{array}{c}0 \\
(0-4.5)\end{array}$ & $\begin{array}{l}3.6 \\
(1.6-6.9)\end{array}$ & $\begin{array}{l}2.6 \\
(0.3-9.2)\end{array}$ & $\begin{array}{l}5.2 \\
(3.4-7.5)\end{array}$ \\
\hline
\end{tabular}

$\mathrm{CI}$, confidence interval (binomial exact).

* Pregnancy diagnosis by ultrasound $>45$ days after service.

** Abortions at pasture between pregnancy diagnosis and $<125$ days of gestation without recovery of fetus.

*** Abortions indoors at $>125$ days of gestation where the fetus was recovered.

Table 2

Bluetongue virus (BTV) serology of clinically normal neonatal lambs prior to colostrum intake (T0) and a T36 h (T36) following access to colostrum ad libitum.

\begin{tabular}{|c|c|c|c|c|c|c|}
\hline Lamb group & Unit & November 2007 & January 2008 & March 2008 & May 2008 & Total \\
\hline Live lambs & Number & 121 & 65 & 216 & 74 & 476 \\
\hline Lambs positive on BTV serology ${ }^{*}$ at T0 & $\begin{array}{l}\text { Number } \\
\text { Percentage } \\
(95 \% \mathrm{CI})\end{array}$ & $\begin{array}{l}7 \\
5.8 \\
(2.4-11.6)\end{array}$ & $\begin{array}{l}1 \\
1.5 \\
(0.04-8.3)\end{array}$ & $\begin{array}{c}1 \\
0.5 \\
(0.01-2.6)\end{array}$ & $\begin{array}{c}0 \\
0 \\
(0-4.0)\end{array}$ & $\begin{array}{c}9 \\
1.9 \\
(0.9-3.6)\end{array}$ \\
\hline Lambs negative on BTV serology at T0 & $\begin{array}{l}\text { Number } \\
\text { Percentage } \\
(95 \% \mathrm{CI})\end{array}$ & $\begin{array}{l}114 \\
94.2 \\
(88.4-97.6)\end{array}$ & $\begin{array}{l}64 \\
98.4 \\
(91.7-99.9)\end{array}$ & $\begin{array}{l}215 \\
99.5 \\
(97.4-99.9)\end{array}$ & $\begin{array}{l}74 \\
100 \\
(96.0-100)\end{array}$ & $\begin{array}{l}467 \\
98.1 \\
(96.4-99.1)\end{array}$ \\
\hline \multirow{2}{*}{$\begin{array}{l}\text { Lambs positive on BTV serology }{ }^{*} \text { at T36 } \\
\text { (born to BTV-positive ewes) }\end{array}$} & Number & 107 & 59 & 204 & 67 & 437 \\
\hline & $\begin{array}{l}\text { Percentage } \\
(95 \% \mathrm{CI})\end{array}$ & $\begin{array}{l}88.4 \\
(81.3-93.5)\end{array}$ & $\begin{array}{l}90.8 \\
(81.0-96.5)\end{array}$ & $\begin{array}{l}94.4 \\
(90.4-97.1)\end{array}$ & $\begin{array}{l}90.5 \\
(81.5-96.1)\end{array}$ & $\begin{array}{l}91.8 \\
(88.9-94.1)\end{array}$ \\
\hline \multirow{2}{*}{$\begin{array}{l}\text { Lambs negative on BTV serology at T36 } \\
\text { (born to BTV-negative ewes) }\end{array}$} & Number & 14 & 6 & 12 & 7 & 39 \\
\hline & $\begin{array}{l}\text { Percentage } \\
(95 \% \mathrm{CI})\end{array}$ & $\begin{array}{l}11.6 \\
(64.7-18.7)\end{array}$ & $\begin{array}{l}9.3 \\
(3.5-19.0)\end{array}$ & $\begin{array}{c}5.6 \\
(2.9-9.5)\end{array}$ & $\begin{array}{c}9.5 \\
(3.9-18.5)\end{array}$ & $\begin{array}{c}8.2 \\
(5.9-11.1)\end{array}$ \\
\hline
\end{tabular}

CI, confidence interval (binomial exact)

Seropositive if percentage of negativity $<66 \%$ 
of $60-75 \%$ in the November 2007 and March 2008 periods. The fertility of ewes lambing in May 2008 was also low. When the fertility of lambing ewes was assessed, a marked decrease in pregnancy rate was noted for ewes lambing in November and was associated with a high $(10 \%)$ percentage of undetected abortions at pasture between days 45 and 125 of gestation. A smaller percentage (1.4\%) of undetected abortions was recorded for ewes lambing in March 2008 and no undetected abortions were found in ewes lambing in January and May 2008.

Abortions occurred much more frequently at the end of gestation during the November 2007 lambing (15.7\%), whereas 0\%, 5.7\% and 3.7\% abortion rates were recorded at the January, March and May 2008 lambings, respectively. Prolificacy ranged from 2.17 for ewes that had been synchronised and lambed in November 2007 to $1.41-1.61$ for non-synchronised animals lambing in January, March and May 2008.

\section{Evidence of in utero BTV-8 infection in clinically normal lambs}

The number and percentage of serologically positive and negative, clinically normal lambs are detailed in Table 2 . Although the majority of lambs were serologically negative prior to colostrum intake, seven (5.8\%) born in November 2007 , one (1.5\%) born in
January 2008 and one (0.5\%) born in March 2008 were seropositive. At T36, most lambs were positive and only those lambs born to BTV-8-negative dams were negative. The percentage of seronegative lambs ranged from $5.6 \%$ to $11.6 \%$ between lambing periods, which corresponded to $2-12 \%$ of BTV-8-negative lambing ewes, as calculated from the prolificacy for each lambing period.

Twenty, randomly selected lambs with negative BTV serology at T0 and all nine lambs with positive T0 serology were re-sampled at D14 (this sampling time was altered to D28 for technical reasons for lambs born in January and March 2008); a PCR was used to detect BTV on RBCs (a sample of spleen was used from lamb 7740_1 as this animal died from septicaemia $<24 \mathrm{~h}$ after birth). No seronegative lambs were positive on PCR (data not shown). Of the nine seropositive animals, the seven born in November 2007 were PCR positive at D14 and the two lambs born in January and March 2008 , respectively were negative (at D28) (Table 3). Virus isolation proved negative.

Samples of placenta from two ewes that lambed in November 2007 were PCR positive as were blood samples from their lambs. Samples could not be collected from the other ewes with PCR-positive lambs (Table 3 ). Five randomly chosen placental samples/ lambing period from ewes that lambed normally and whose lambs were seronegative at T0, were assessed by PCR. Positive results

Table 3

Results of bluetongue virus (BTV) ELISA and PCR from ewes and lambs infected in utero, before and $36 \mathrm{~h}$ after colostrum intake.

\begin{tabular}{|c|c|c|c|c|c|c|}
\hline \multirow[t]{2}{*}{ Lambing period } & \multicolumn{2}{|l|}{ Ewe } & \multicolumn{4}{|l|}{ Lambs } \\
\hline & $\begin{array}{l}\text { Percentage negativity } \\
\text { serology }\end{array}$ & $\begin{array}{l}\text { PCR on placenta** } \\
\text { (Ct value) }\end{array}$ & $\begin{array}{l}\text { Lamb } \\
\text { identity }\end{array}$ & $\begin{array}{l}\text { Percentage negativity } \\
\text { serology T0 }\end{array}$ & $\begin{array}{l}\text { Percentage negativity } \\
\text { serology T36 }\end{array}$ & $\begin{array}{l}\text { PCR on red blood } \\
\text { cells D } 14 \text { (Ct value) }\end{array}$ \\
\hline \multirow[t]{3}{*}{ November 2007} & 6 & No sample & 1088 & 11 & 5 & 32.1 \\
\hline & & & 1089 & 11 & 8 & 32.1 \\
\hline & & & 1090 & 3 & 5 & 30.1 \\
\hline \multirow[t]{2}{*}{ November 2007} & 4 & No sample & 4862 & 30 & 4 & 32.8 \\
\hline & & & 4863 & 32 & 5 & 38.6 \\
\hline November 2007 & 4 & 31.5 & 4879 & 9 & 13 & 38.9 \\
\hline November 2007 & 14 & 37.6 & $7740 \_1^{* * * *}$ & 9 & No sample & 38.8 (spleen) $)^{* * *}$ \\
\hline January 2008 & 8 & No sample & 4919 & 23 & 9 & Negative ${ }^{* * * *}$ \\
\hline March 2008 & 6 & No sample & 5844 & 34 & 13 & Negative $e^{* * * * *}$ \\
\hline
\end{tabular}

T0 = at birth, T36 = $36 \mathrm{~h}$ after birth.

* Positive if percentage $<66 \%$.

*** Positive if $\mathrm{Ct}$ value $<40$.

**** Lamb 7740_1 died of septicaemia $24 \mathrm{~h}$ after birth. A sample of spleen was analysed by PCR.

***** Blood only sampled at D28.

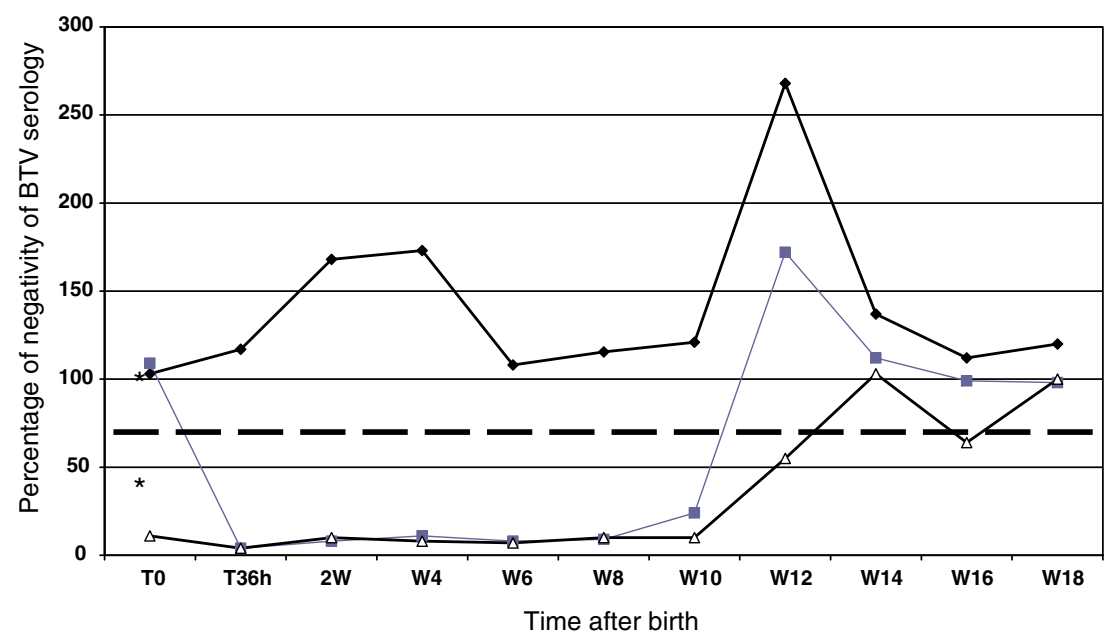

Fig. 1. Results of serology expressed as a 'percentage of negativity' of lambs born to: bluetongue virus (BTV)-8-negative ewes (,$n=7)$; BTV-8-positive ewes without (

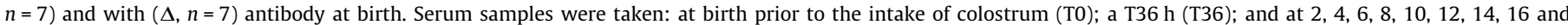

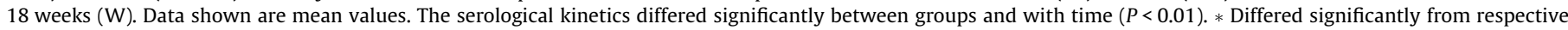
T36 value $(P<0.05)$. 
were found in three samples in November 2007 and in two samples in January and March 2008, respectively. None of the samples collected in May 2008 were positive (data not shown). Tests for Chlamydophila abortus and Coxiella burnetii were negative.

Findings of the follow-up serology on the seven antibody- and PCR-positive lambs and on the seronegative lambs born to BTV8-positive and negative ewes is illustrated in Fig. 1. A two-factor ANOVA with repeated measures on one factor was used to compare the results between these groups and found significant differences in the kinetics of percentage inhibition $(P<0.01)$ as well as in group-time interaction $(P<0.01)$. While lambs born to BTV-8-negative ewes remained negative at follow-up, lambs born to BTV-8positive animals exhibited significantly different antibody profiles. The percentage of negativity of negative lambs at T0 had decreased significantly by T36 (108 $\pm 3 \%$ compared to $4.0 \pm 0.3 \%, P<0.001)$ and then increased progressively. By approximately 12 weeks of

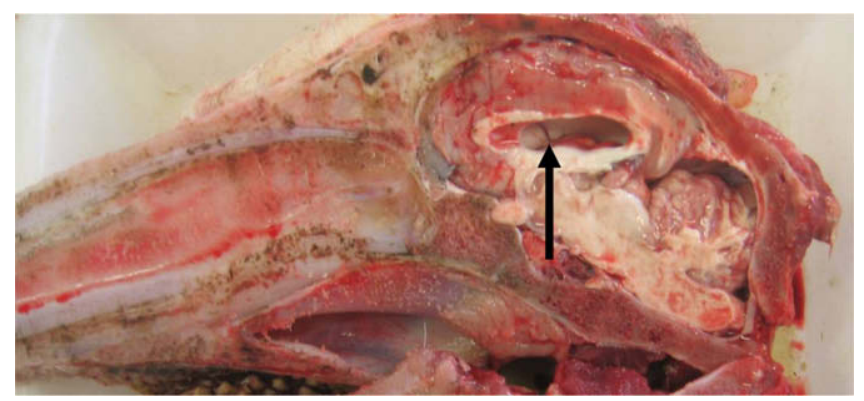

Fig. 2. Photograph of a dilated lateral ventricle (arrow) in the cerebrum of a 5 month old lamb. The lamb was born to a bluetongue virus (BTV)-8-positive ewe, exhibited severe neurological signs at birth and was seropositive for BTV prior to colostrum intake. age the percentage of negativity in-lambs was > the cut-off of $66 \%$. Antibody concentrations in-lambs serologically and PCR positive at T0 decreased significantly in terms of percentage of negativity by $\mathrm{T} 36(18.6 \pm 12.7 \%$ compared to $6.3 \pm 6.5 \%, P<0.05)$. The progressive increase in the percentage of negativity above the cut-off level paralleled that of the preceding group (no significant differences between groups) but remained low, even after 18 weeks.

\section{Findings in 'dummy' lamb with neurological deficits}

An antibody-positive lamb born in November 2007 exhibited severe neurological deficits. The animal was unable to stand unaided, had a left head-tilt and turned towards its left side during its first days of life (see Supplementary data - Video 1). On some days, the head-tilt was to the right and the animal turned towards its right side (see Supplementary data - Video 2). The lamb had normal auditory and visual responses and the pupillary reflexes were normal. Since it was unable to suckle unaided, the lamb was fed manually with milk but eventually was able to eat concentrates and hay. At weaning, this lamb was kept in a small group with other lambs. Following euthanasia at 5 months old, post-mortem examination revealed dilation of both cerebral lateral ventricles (Fig. 2). PCR examination of RBCs at D14 and of spleen and cerebral samples at euthanasia, was negative.

Evidence for in utero BTV-8 infection of fetuses resulting in late-term abortion

Table 4 provides details on the 21 ewes that presented with late-term abortion and whose fetuses were available for necropsy

Table 4

Results of serology for bluetongue virus (BTV) in ewes presenting with late-term abortion and of PCR detection and necropsy findings in the fetuses and placentae.

\begin{tabular}{|c|c|c|c|c|c|}
\hline \multirow[t]{2}{*}{ Number } & \multirow[t]{2}{*}{ Lambing period } & \multicolumn{2}{|l|}{ Ewe } & \multicolumn{2}{|l|}{ Fetus } \\
\hline & & $\begin{array}{l}\text { Percentage of negativity } \\
\text { for BTV antibodies }\end{array}$ & $\begin{array}{l}\text { PCR on placenta } \\
\text { (Ct value) }\end{array}$ & $\begin{array}{l}\text { PCR on spleen } \\
\text { (Ct value) }\end{array}$ & Necropsy findings \\
\hline 1 & November 2007 & 4 & 37.6 & 38.8 & \\
\hline 2 & November 2007 & 6 & No sample ${ }^{a}$ & No result ${ }^{\mathrm{b}}$ & $\begin{array}{l}\text { Brachycephaly with brachygnathia superior. Non-fusion of } \\
\text { mandibles with a gingival vascular hamartoma }\end{array}$ \\
\hline 3 & November 2007 & 133 & No sample & Negative & \\
\hline 4 & November 2007 & 4 & No sample & 39.9 & \\
\hline 5 & November 2007 & 3 & No sample & No result & $\begin{array}{l}\text { Hydranencephaly. Non-fusion of mandibles. Arthrogryposis } \\
\text { of both fore- and hind-legs }\end{array}$ \\
\hline 6 & November 2007 & 4 & No sample & No result & \\
\hline 7 & November 2007 & 4 & No sample & No result & No macroscopic abnormalities \\
\hline 8 & November 2007 & 5 & No sample & No result & $\begin{array}{l}\text { Brachycephaly with brachygnathia superior. Advanced } \\
\text { autolysis }\end{array}$ \\
\hline 9 & November 2007 & 7 & No sample & No result & \\
\hline 10 & November 2007 & 5 & No sample & 39.9 & No macroscopic abnormalities \\
\hline 11 & November 2007 & 6 & No sample & No sample & No macroscopic abnormalities \\
\hline 12 & March 2008 & 8 & No result & No result & $\begin{array}{l}\text { Brachycephaly with brachygnathia superior. Non-fusion of } \\
\text { mandibles with a gingival vascular hamartoma. Porencephaly } \\
\text { and dilated lateral ventricles. Advanced autolysis }\end{array}$ \\
\hline 13 & March 2008 & 9 & No sample & No result & $\begin{array}{l}\text { Brachycephaly with brachygnathia superior. Non-fusion of } \\
\text { mandibles with a gingival vascular hamartoma }\end{array}$ \\
\hline 14 & March 2008 & 5 & No sample & No sample & $\begin{array}{l}\text { Brachycephaly with brachygnathia superior. Absence of } \\
\text { cerebellum }\end{array}$ \\
\hline 15 & March 2008 & 6 & No sample & No result & Brachycephaly with brachygnathia superior. Anophthalmia \\
\hline 16 & March 2008 & 6 & Negative & 43.6 & No abnormal findings \\
\hline 17 & March 2008 & 8 & No sample & No result & $\begin{array}{l}\text { Brachycephaly with brachygnathia superior. Non-fusion of } \\
\text { mandibles with a gingival vascular hamartoma. Absence of } \\
\text { cerebellum }\end{array}$ \\
\hline 18 & March 2008 & 13 & No result & No result & Non-fusion of mandibles with a gingival vascular hamartoma \\
\hline 19 & March 2008 & 7 & No sample & 39.9 & $\begin{array}{l}\text { Coelosomy with severe scoliosis. Coxofemoral malformation. } \\
\text { Absence of anus and vulva. Arthrogryposis }\end{array}$ \\
\hline 20 & May 2008 & 6 & No sample & Negative & No macroscopic abnormalities \\
\hline 21 & May 2008 & 7 & No sample & Negative & No macroscopic abnormalities \\
\hline
\end{tabular}

a No sample $=$ collection of placental samples not possible because of advanced tissue autolysis.

b No result $=$ PCR analyses inconclusive because of advanced tissue autolysis. 


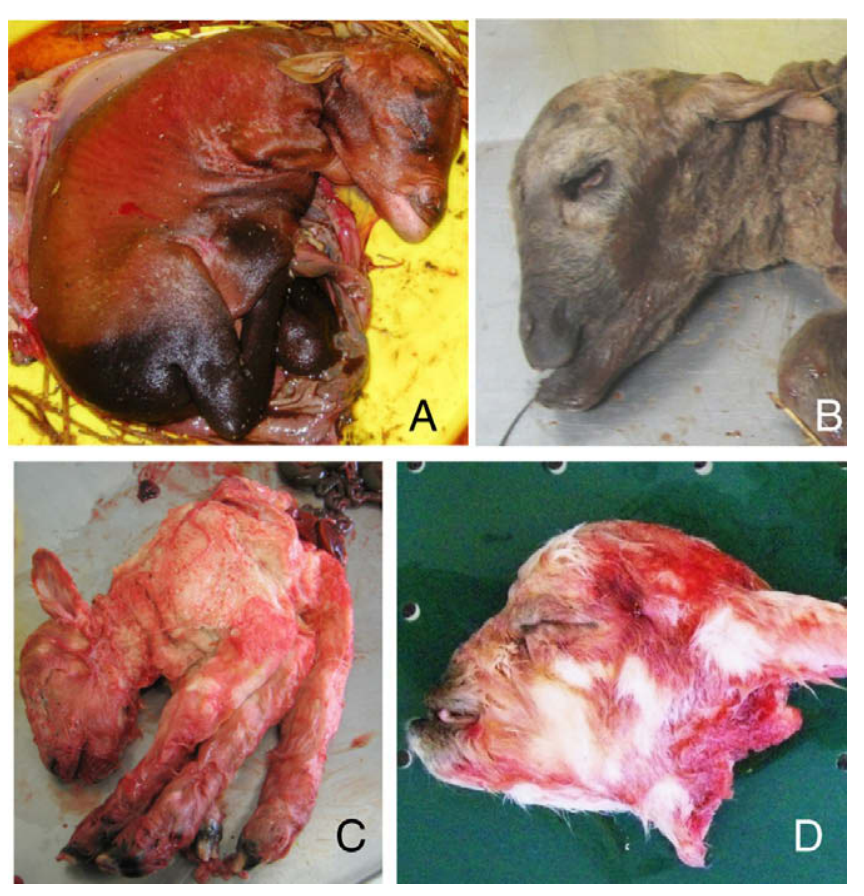

Fig. 3. Photographs illustrating aborted lamb fetuses in advanced autolysis with: (A) Brachycephaly and brachygnathia superior. (B) Anophthalmia and brachygnathia superior. (C) Aborted female lamb fetus delivered by caesarean section exhibiting coelosomy, severe scoliosis, coxofemoral malformation, an absence of both anus and vulva and arthrogryposis. (D) Lateral view of head of an aborted fetus with severe brachycephaly and brachygnathia superior.
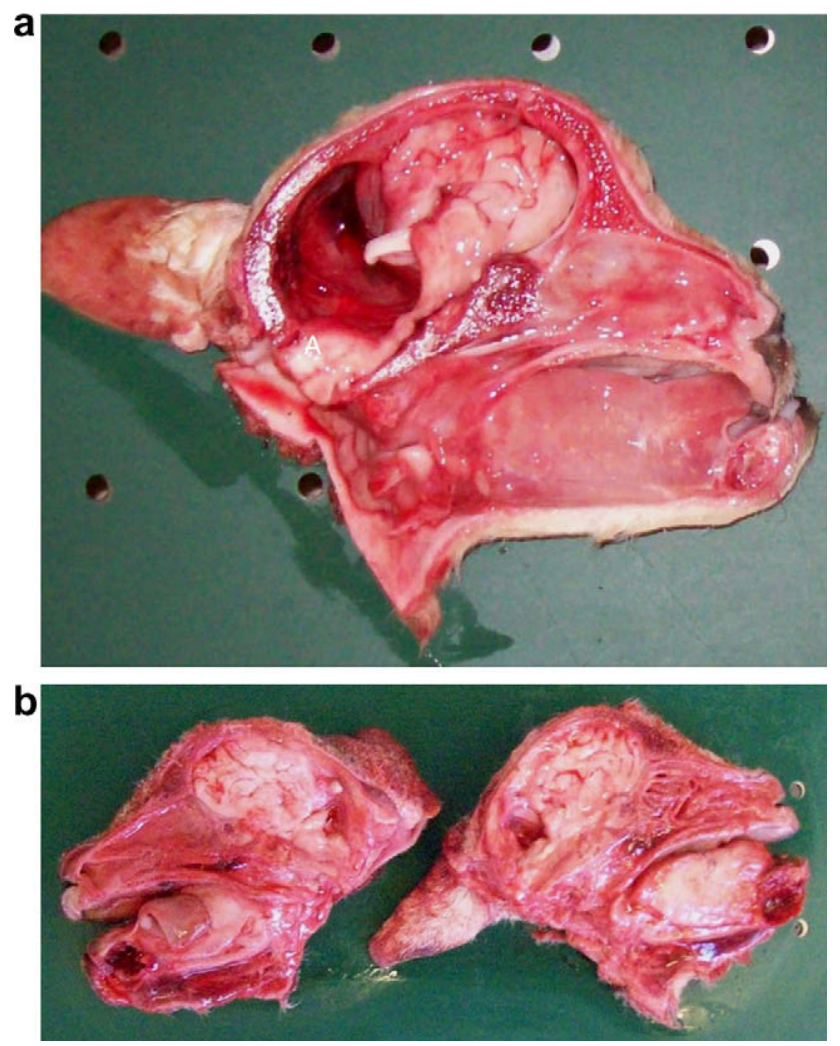

Fig. 4. Photographs of sagittal sections of the skulls of aborted fetuses with: (A) cerebellar aplasia and (B) cerebellar hypoplasia and non-fusion of the mandibles with a gingival vascular hamartoma.

and PCR analysis. All ewes except for one (No. 3) were seropositive. Most abortions occurred during the lambing of November 2007. Placental samples were not available in all cases because of placen-
Table 5

Culicoides spp. midge count after a $24 \mathrm{~h}$ trapping period performed four times monthly indoors and at pasture. Adult sheep were permanently present indoors and on the pasture where trappings were performed.

\begin{tabular}{lcc}
\hline Trapping period & $\begin{array}{l}\text { Number of Culicoides } \\
\text { spp. trapped indoors }\end{array}$ & $\begin{array}{l}\text { Number of Culicoides } \\
\text { spp. trapped at pasture }\end{array}$ \\
\hline August 2007 & $13,705^{*}$ & 414 \\
September 2007 & 2120 & 303 \\
October 2007 & 1585 & 390 \\
November 2007 & 29 & 11 \\
December 2007 & 7 & 0 \\
January 2008 & 0 & 0 \\
February 2008 & 2 & 0 \\
March 2008 & 0 & 0 \\
April 2008 & 3 & 345 \\
\hline
\end{tabular}

Corresponds to three trappings and counts due to a technical difficulty.

tal retention and autolysis. As a consequence only one placental sample was found to be positive on PCR.

Although examination of many of the fetal samples was not possible because of advanced autolysis, three were found positive and one inconclusive from the November 2007 and March 2008 lambing periods. Analysis of fetal tissue from the May 2008 lambing period proved negative. Macroscopically visible abnormalities found in fetuses included brachycephaly, hydranencephaly, brachygnathia superior, non-fusion of the mandibles associated a gingival vascular hamartoma and cerebellar aplasia (Figs. 3 and 4). Some of the fetuses were small $(<2 \mathrm{~kg})$ and markedly putrefied at the time of abortion (Fig. 3 ), whereas others were almost normal in size (3-4 kg) and exhibited minimal post-mortem decomposition, indicating that they probably died shortly before they were aborted (Fig. 3).

\section{Indoor and outdoor insect vector activity}

Culicoides spp. counts are detailed in Table 5. Activity was maximal in the summer of 2007, was markedly reduced by November, was negligible during the winter and early spring and started rising again in April 2008. The number of trapped insects was higher indoors than outdoors.

\section{Discussion}

This study provides strong evidence that trans-placental infection with BTV-8 occurs in naturally-infected sheep. It facilitates an assessment of the impact of BTV-8 infection on flock reproductive parameters and the findings suggest this viral infection may over-winter in pregnant sheep and their lambs.

Our data indicate that in utero infection of pregnant sheep with BTV-8 can result in abortion or the birth of live lambs. Of the $21 \mathrm{de}-$ tected late-term abortions, three were positive and a further was doubtful on PCR. Similar findings have been recorded in bovine fetuses (De Clercq et al., 2008). Given that detection of BTV in the central nervous system (CNS) by PCR appears more sensitive (De Clercq et al., 2008), analysis of the CNS in the present study may have provided further useful information. However, such examinations were not possible in our study because of the advanced degree of autolysis. This tissue decomposition may also account for the unsuccessful attempts at virus isolation from PCR-positive samples and our method of sample storage at $-20^{\circ} \mathrm{C}$ may also have reduced virus survival in tissues (Lefèvre et al., 2008).

PCR analysis of placental samples from ewes that aborted was attempted and one was found positive although, in general, the collection of such samples was unsuccessful because of frequent placental retention and autolysis. Our post-mortem findings in the lambs are similar to those described in BTV-8 infected calves 
(Desmecht et al., 2008; Vercauteren et al., 2008) and to lesions induced by other BTV serotypes (MacLachlan et al., 2000). The most frequent macroscopic finding was brachycephaly with brachygnathia superior, followed by cerebral abnormalities. Unfortunately it was not possible to carry out histopathological examination of the CNS.

Ewes that presented with late-term abortion, BTV-8 PCR positive fetuses and fetuses with bluetongue lesions post-mortem were all seropositive, although their PCR BTV-8 status at the time of abortion was not determined. The flock was known to be free of Border disease and of infection with Toxoplasma gondii, Coxiella burnettii and Chlamydophila abortus. Of the 476 healthy lambs born between November 2007 and May 2008, nine had antibodies at birth prior to colostrum intake and were born to six ewes seropositive at lambing. PCR analysis of RBCs from these lambs proved positive when sampled within 14 days of birth. This finding may have resulted from the ingestion of BTV-8-infected leucocytes along with the colostrum or from de novo infection via insect bites.

Although PCR analysis was not carried out on colostrum in the present study, oral infection with BTV-8 has been demonstrated through the ingestion of placental material (Alexander et al., 1994; Jauniaux et al., 2008). However, Worwa et al. (2009) did not find virus in the colostrum of an experimentally infected ewe on PCR. With regard to the possibility of vector infection, PCR-positive lambs were born in November 2007 when vectors were not detected and several lambs born to naïve ewes remained virus negative until early April 2008. The fact that BTV-8 related abortions occurred at the same time favours the likelihood of in utero infection and viraemia at $\mathrm{T} 0$.

The failure to isolate virus from the RBCs of lambs with PCR-positive samples may have been due to the effects of neutralising antibodies from the colostrum. The fact that RBCs from two lambs sampled at D28 were PCR-negative may have been due to the shorter life span of neonatal erythrocytes (Brace et al., 2000). Although confirmation of infection is lacking in the lamb with neurological signs born in November 2007, the CNS lesions observed are strongly suggestive of BTV infection as described in calves (Vercauteren et al., 2008). Such teratogenic effects likely follow in utero viral infection during early fetal development, so that later-stage PCR assessment for the presence of virus may prove negative (Vercauteren et al., 2008).

Bluetongue impacts on the reproductive performance of both female and male ruminants (Oberst, 1993; Osburn, 1994; MacLachlan et al., 2000; Breard et al., 2007). While the effect of natural BTV-8 infection on semen quality has already been reported (Kirschvink et al., 2009), the present findings reflect the impact of infec- tion on the reproductive performance of ewes. As the rams had undergone regular semen quality assessment and were free of BTV-8 infection until June or July 2007 (data not shown), it seems reasonable to assume that reproductive deficits related mainly to infection of the ewes. However, rams that were used in August 2007, October 2007 and January 2008 had almost all been infected by BTV-8 during the summer of 2007. Although the semen quality of these animals was similar to that of rams used by insemination centres, transmission of BTV-8 through semen transfer cannot be excluded as PCR analysis of semen was not carried out.

Most losses due to abortion were recorded in the first group of ewes, in-lamb since early July 2007. When the fertility of these ewes at the time of pregnancy diagnosis was compared with their fertility at lambing, a decrease from $70 \%$ to $63 \%$ was recorded due to seven abortions at pasture before day 125 of gestation. However, of the 63 lambing ewes, 11 aborted late-term so that $25.7 \%$ of abortions occurred between day 45 and lambing during this first gestation period. These results indicate that during periods of presumed maximal vector activity (i.e. August 2007), the impact of BTV-8 infection during early pregnancy was considerable resulting in abortion and in utero infection of a small percentage of viable lambs.

During the second lambing period, no abortions occurred, but fertility was markedly reduced compared to previous years. Although it is possible that the reduced body condition of the ewes prolonged seasonal anoestrus (Kirschvink, 2009), as most of the ewes had been mounted by the rams, it is more likely that BTV-induced embryonic or early fetal death occurred as has been reported experimentally (Thomas et al., 1986; de la ConchaBermejillo et al., 1993; Parsonson et al., 1994; Housawi et al., 2004). Furthermore, vector activity during early gestation (end of August 2007) was still relatively high. An assessment of BTV-8 RNA and of pregnancy-associated proteins in these ewes would have been useful in further elucidating this aspect of the study.

The third lambing period was characterised by fertility percentages near to reference values for the flock (65-75\%), low numbers of undetected abortions (1.4\%) and 5.7\% late-term abortions. Given the $88 \%$ seroprevalence in the flock in November 2007, the percentage of BTV-susceptible ewes was much lower than in July, and vector activity at the end of October 2007 was also greatly reduced. In consequence, the impact of trans-placental BTV infection in terms of abortion and in utero infection was reduced.

During the fourth mating period in January 2008, insect vector activity was zero. By the end of pregnancy in May, vector activity had increased, but remained low relative to the activity recorded in late summer 2007. The percentage of BTV naïve animals was also low at this time $(<12 \%)$ and both factors probably contributed

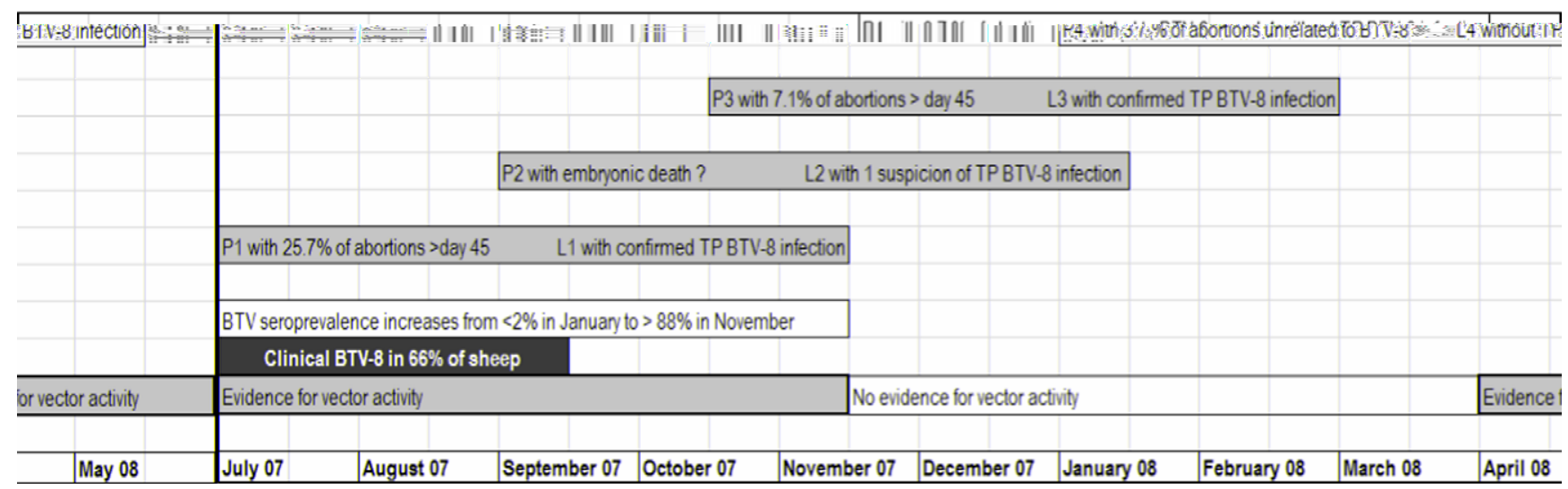

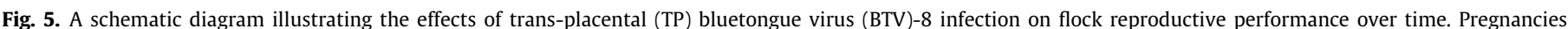

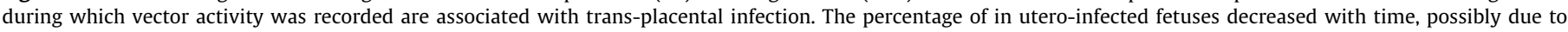
decreased vector activity and increasing flock immunity. P, pregnancy period; L, lambing period. 
to the absence of evidence of trans-placental infection and to fertility rates within the flock's reference value for this period. A slightly higher late-term abortion rate was recorded in this group, as at least $50 \%$ of the ewes were primiparous.

This investigation over four lambing periods gives some insights into the kinetics of BTV-8 infection in a naïve sheep flock. At the end of vector activity in November $2007,88 \%$ of sheep were antibody positive and infection at this stage may have facilitated trans-placental infection and the birth or abortion of infected fetuses in March 2008. The finding of PCR-positive placental and splenic samples in November 2007 and in January and March 2008 further suggested that infection occurred late in the year and the possibility of persistence of virus in placentae for several months. This finding supports the theory that BTV-8 over-winters following trans-placental passage in sheep.

Overall, the decrease in the number of abortions and of seropositive lambs at T0, along with the number of PCR-positive viable lambs, suggest that the risk of trans-placental infection decreases with time, commensurate with reduced vector activity (Fig. 5). Even if all seropositive lambs were potentially infective, $1.9 \%$ of all lambs were capable of infecting an insect vector. These potentially infective lambs were born during vector-free periods and ingested significant amounts of BTV-8 neutralising antibodies in the colostrum. Our lack of success in isolating virus from PCR-positive RBCs from animals at D14, as well the PCR-negative results from the D28 lambs support the theory that infected lambs contribute little to BTV-8 over-wintering. Moreover, the follow-up serological assessment on presumed in utero-infected lambs indicated that active immunity was reinforced by colostral immunity. Such maternally acquired immunity decreases progressively over 15 weeks, as described in haemorrhagic disease virus infection in White-tailed deer, while active immunity appears to persist at a low level in some animals (Gaydos et al., 2002).

\section{Conclusions}

The evidence provided by this investigation strongly suggests that trans-placental BTV-8 infection occurs in naturally-infected sheep. The impact of the BTV-8 infection on the reproductive performance of such a naïve flock was considerable, resulting in up to $25 \%$ of the ewes aborting and reducing the fertility rate by $50 \%$. The contribution of in utero-infected lambs to the over-wintering of BTV appears to be limited.

\section{Conflict of interest statement}

None of the authors of this paper has a financial or personal relationship with other people or organisations that could inappropriately influence or bias the content of the paper.

\section{Acknowledgements}

The authors wish to thank Nicolas Mauguit and Marc-Antoine Bourdon (University of Namur) for helpful technical assistance with animals and sample analyses and gratefully acknowledge the help of Delphine Cassart (University of Namur) for setting the manuscript. The Federal Agency for the Safety of the Food Chain (FASFC, Drs. J. Hooyberghs and P. Houdart) are gratefully acknowledged for supporting the costs of PCR analyses and virus isolation performed by VAR.

\section{Appendix A. Supplementary material}

Supplementary data associated with this article can be found, in the online version, at doi:10.1016/j.tvjl.2009.11.012.

\section{References}

Alexander, K.A., MacLachlan, N.J., Kat, P.W., House, C., O’Brien, S.J., Lerche, N.W. Sawyer, M., Frank, L.G., Holekamp, K., Smale, L., 1994. Evidence of natural bluetongue virus infection among African carnivores. The American Journal of Tropical Medicine and Hygiene 51, 568-576.

Brace, R.A., Langendorfer, C., Song, T.B., Mock, D.M., 2000. Red blood cell life span in the ovine fetus. American Journal of Physiology 279, R1196-R1204.

Breard, E., Pozzi, N., Sailleau, C., Durand, B., Catinot, V., Sellem, E., Dumont, P. Guerin, B., Zientara, S., 2007. Transient adverse effects of an attenuated bluetongue virus vaccine on the quality of ram semen. Veterinary Record 160, 431-435.

Campbell, S.G., Siegel, M.J., Knowlton, B.J., 1977. Sheep immunoglobulins and their transmission to the neonatal lamb. New Zealand Veterinary Journal 25, 361365.

De Clercq, K., de Leeuw, I., Verheyden, B., Vandemeulebroucke, E., Vanbinst, T., Herr C., Meroc, E., Bertels, G., Steurbaut, N., Miry, C., De Bleecker, K., Maquet, G., Bughin, J., Saulmont, M., Lebrun, M., Sustronck, B., De Deken, R., Hooyberghs, J., Houdart, P., Raemaekers, M., Mintiens, K., Kerkhofs, P., Goris, N., Vandenbussche, F., 2008. Transplacental infection and apparent immunotolerance induced by a wild-type bluetongue virus serotype 8 natural infection. Transboundary Emerging Diseases 55, 352-359.

de la Concha-Bermejillo, A., Odeon, A., BonDurant, R.H., Osburn, B.I., 1993. Experimental infection of pregnant cattle with bluetongue virus serotype 11 between postbreeding days 21 and 48 . Journal of Veterinary Diagnostic Investigation 5, 329-335.

Desmecht, D., Bergh, R.V., Sartelet, A., Leclerc, M., Mignot, C., Misse, F., Sudraud, C. Berthemin, S., Jolly, S., Mousset, B., Linden, A., Coignoul, F., Cassart, D., 2008. Evidence for transplacental transmission of the current wild-type strain of bluetongue virus serotype 8 in cattle. Veterinary Research 163, 50-52.

Elbers, A.R., Mintiens, K., Staubach, C., Gerbier, G., Meiswinkel, R., Hendrinckx, G., Backx, A., Conraths, F.J., Meroc, E., Ducheyne, E., Gethmann, J., Heesterbeek, J.A.P., De Clerq, K., Unger, F., Stegeman, J.A., 2007. Bluetongue virus serotype 8 epidemic in North-western Europe in 2006: preliminary findings. In: Proceedings of the Annual Meeting of the Society for Veterinary Epidemiology and Preventive Medicine, Dipoli, Finland, pp. 231-245.

Federal Agency for the Safety of the Food Chain (FASFC) of Belgium, 2007. <http:// www.afsca.be/crisis/sa-blueT/catarrhale_fr.asp>.

Gaydos, J.K., Stallknecht, D.E., Kavanaugh, D., Olson, R.J., Fuchs, E.R., 2002. Dynamics of maternal antibodies to hemorrhagic disease viruses (Reoviridae: Orbivirus) in white-tailed deer. Journal of Wildlife Diseases 38, 253-257.

Housawi, F.M., bu Elzein, E.M., Ramadan, R.O., Gameel, A.A., Al-Afaleq, A.I., AlMousa, J., 2004. Abortions, stillbirths and deformities in sheep at the Al-Ahsa oasis in Eastern Saudi Arabia: isolation of a bluetongue serogroup virus from the affected lambs. Revue Scientifique et Technique (International Office of Epizootics) 23, 913-920.

Jauniaux, T.P., De Clercq, K.E., Cassart, D.E., Kennedy, S., Vandenbussche, F.E., Vandemeulebroucke, E.L., Vanbinst, T.M., Verheyden, B.I., Goris, N.E., Coignoul, F.L., 2008. Bluetongue in Eurasian lynx. Emerging Infectious Diseases 14, 14961498.

Kirschvink, N., 2009. Verlauf von Blauzungenkrankheit in einem Schafbestand in Belgien und Hinweise in auf eine vertikale Übertragung. Deutsche Tierärztliche Wochschenschrift 116, 70.

Kirschvink, N., Raes, M., Saegerman, C., 2009. Impact of a natural bluetongue serotype- 8 infection on semen quality of Belgian rams in 2007. The Veterinary Journal 182, 244-251

Lefèvre, P.C., Mellor, P.S., Saegerman, C., 2008. Bluetongue. In: Lavoisier, S.A.S. (Ed.), Infectious and Parasitic Disease of Livestock, Provigny, France, pp. 959-989.

MacLachlan, N.J., 1994. The pathogenesis and immunology of bluetongue virus infection of ruminants. Comparative Immunology, Microbiology and Infectious Diseases 17, 197-206.

MacLachlan, N.J., Osburn, B.I., Ghalib, H.W., Stott, J.L., 1985. Bluetongue virusinduced encephalopathy in fetal cattle. Veterinary Pathology 22, 415-417.

MacLachlan, N.J., Conley, A.J., Kennedy, P.C., 2000. Bluetongue and equine viral arteritis viruses as models of virus-induced fetal injury and abortion. Animal Reproduction Science 60-61, 643-651.

Mellor, P.S., Wittmann, E.J., 2002. Bluetongue virus in the Mediterranean basin 1998-2001. The Veterinary Journal 164, 20-37.

Oberst, R.D., 1993. Viruses as teratogens. Veterinary Clinics of North America, Food Animal Practice 9, 23-31.

Osburn, B.I., 1994. The impact of bluetongue virus on reproduction. Comparative Immunology, Microbiology and Infectious Diseases 17, 189-196.

Parsonson, I.M., Thompson, L.H., Walton, T.E., 1994. Experimentally induced infection with bluetongue virus serotype 11 in cows. American Journal of Veterinary Research 55, 1529-1534.

Saegerman, C., Hubaux, M., Urbain, B., Lengele, L., Berkvens, D., 2007. Regulatory issues surrounding the temporary authorisation of animal vaccination in emergency situations: the example of bluetongue in Europe. Revue Scientifique et Technique (International Office of Epizootics) 26, 395-413.

Saegerman, C., Berkvens, D., Mellor, P.S., 2008a. Bluetongue epidemiology in the European Union. Emerging Infectious Diseases 14, 539-544.

Saegerman, C., Raes, M., Uyttenhoef, A., Hanon, J.B., Fecher, F., Kirschvink, N., 2008b. Estimation préliminaire de l'impact économique induit par l'infection naturelle par le serotype 8 du virus de la fièvre catarrhale ovine (FCO) en élevage ovin (Belgique, Novembre, 2007). Epidémiologie et Santé Animale 54, 115-120. 
Thomas, F.C., Randall, G.C., Myers, D.J., 1986. Attempts to establish congenita bluetongue virus infections in calves. Canadian Journal of Veterinary Research $50,280-281$

Toussaint, J.F., Sailleau, C., Breard, E., Zientara, S., De Clercq, C., 2007a. Bluetongue virus detection by two real-time RT-qPCRs targeting two different genomic segments. Journal of Virological Methods 140, 115-123.

Toussaint, J.F., Sailleau, C., Mast, J., Houdart, P., Czaplicki, G., Demeestere, L., Vandenbussche, F., van, D.W., Goris, N., Breard, E., Bounaadja, L., Etienne, T. Zientara, S., De Clercq, C., 2007b. Bluetongue in Belgium, 2006. Emerging Infectious Diseases 13, 614-616.

Vandenbussche, F., Vanbinst, T., Verheyden, B., van, D.W., Demeestere, L., Houdart, P., Bertels, G., Praet, N., Berkvens, D., Mintiens, K., Goris, N., De Clercq, C. 2008 Evaluation of antibody-ELISA and real-time RT-PCR for the diagnosis and profiling of bluetongue virus serotype 8 during the epidemic in Belgium in 2006. Veterinary Microbiology 129, 15-27.
Vercauteren, G., Miry, C., Vandenbussche, F., Ducatelle, R., Van der, H.S., Vandemeulebroucke, E., De Leeuw, I., Deprez, P., Chiers, K., De Clercq, C. 2008. Bluetongue virus serotype 8-associated congenital hydranencephaly in calves. Transboundary and Emerging Diseases 55, 293-298.

Wilson, A., Mellor, P., 2008. Bluetongue in Europe: vectors, epidemiology and climate change. Parasitology Research 103, S69-S77.

Worwa, G., Hilbe, M., Ehrensperger, F., Chaignat, V., Hofmann, M.A., Griot, C., MacLachlan, N.J., Thuer, B., 2009. Experimental transplacental infection of sheep with bluetongue virus serotype 8. Veterinary Record 164, 499-500.

Wouda, W., Roumen, M.P., Peperkamp, N.H., Vos, J.H., van Garderen, E., Muskens, J., 2008. Hydranencephaly in calves following the bluetongue serotype 8 epidemic in The Netherlands. Veterinary Record 162, 422-423. 